\title{
Introduction
}

\section{Kinds of Children}

Wahlberg, Ayo; Gammeltoft, Tine

Published in:

Selective Reproduction in the 21 st Century

DOI:

10.1007/978-3-319-58220-7 1

Publication date:

2017

Document version

Publisher's PDF, also known as Version of record

Citation for published version (APA):

Wahlberg, A., \& Gammeltoft, T. (2017). Introduction: Kinds of Children. In A. Wahlberg, \& T. M. Gammeltoft

(Eds.), Selective Reproduction in the 21st Century (pp. 1-24). Palgrave Macmillan. https://doi.org/10.1007/978-3-

319-58220-7 1 
This chapter is from Selective Reproduction in the $21^{\text {st }}$ Century, and the final (edited, revised and typeset) version can be found in the edited volume published by Palgrave Macmillan (2017).

\section{Chapter 1}

\section{Introduction - Kinds of Children}

Ayo Wahlberg \& Tine M. Gammeltoft

This book is about selective reproduction in the $21^{\text {st }}$ century. Although selective reproductive practices have existed for a long time (Gammeltoft \& Wahlberg 2014), $21^{\text {st }}$ century biomedicine provides historically unprecedented possibilities for technological interventions in childbearing processes. In the past forty years, human reproduction has been technologically parcelled out into specialised fields of insemination, fertilisation, implantation, gestation, termination and (preterm) birth. Such developments have separated reproduction from sex as well as genetics from gestation. As such, in the $21^{\text {st }}$ century, selective reproduction increasingly takes place through decisions about which gametes to fertilise, which embryos to implant, or which foetuses to abort. These new possibilities for decision-making and choice raise urgent questions for social scientists.

In this volume, we use the term selective reproduction to refer to practices that aim to prevent or promote the birth of particular kinds of children. What we collectively show in the following chapters is how selective reproductive technologies (SRTs) have been developed and routinized - which is to say taken up, practiced, and experienced - around the world over the last few decades. Selective reproduction is ubiquitous and not limited to any specific parts of the world, although the ways in which SRTs gain traction and stabilise are multiple. With the increasing availability of SRTs, selective reproduction is taking place on a historically unprecedented scale; through sex-selective abortion following ultrasound scans, abortion following detection of foetal 
This chapter is from Selective Reproduction in the $21^{\text {st }}$ Century, and the final (edited, revised and typeset) version can be found in the edited volume published by Palgrave Macmillan (2017).

anomalies during routinized prenatal screening and testing programmes, the development of preimplantation genetic diagnosis techniques as well as the screening of potential gamete donors by egg agencies and sperm banks (see Table 1$)^{1}$

\section{From 'helping hand' to 'guiding hand'}

Over the last three decades or so, social scientists have followed assisted reproductive technologies (ARTs) on routes of routinization and globalization, examining their development by clinicians and scientists as well as their impact on the daily lives of involuntarily childless couples in different cultural and socio-economic settings. Indeed, Marilyn Strathern's reflections on such reproductive technologies as 'nature assisted' have provided an entire generation of social scientists with conceptual tools for analysing supposed nature-artifice divides in the field of human reproduction as well as for troubling separations of the natural from the social. "Nature assisted", as she wrote in Reproducing the Future, "compromises the definition of nature as those conditions of life from which intervention is absent; what is given is no longer given by nature itself but is visibly circumscribed by technological capacity" (1992: 57). Writing in the early years of reproductive technologies, Strathern was referring mostly to ARTs: "artificial insemination, in-vitro fertilisation, or other practices such as GIFT (gamete intra-fallopian transfer) simply stand in, so the justification goes, for natural body processes" (Strathern 1998: 186). "If nature can't deliver" as one medical company put it in early 1990s marketing material, then "nature sometimes needs a helping hand" (Strathern 1992: 56, 57). 
This chapter is from Selective Reproduction in the $21^{\text {st }}$ Century, and the final (edited, revised and typeset) version can be found in the edited volume published by Palgrave Macmillan (2017).

\begin{tabular}{|c|c|c|}
\hline Objective of selection & Type of selection (SRT) & Scope \\
\hline $\begin{array}{l}\text { Selecting for desired sex } \\
\text { (sex selection) }\end{array}$ & $\begin{array}{l}\text { - Sex selective abortion following prenatal } \\
\text { determination of foetal sex } \\
\text { - Sex selective implantation of embryos } \\
\text { following in vitro fertilization (IVF) and } \\
\text { embryo biopsy (PGD) } \\
\text { - Sex selective fertilization of gametes } \\
\text { following the MicroSorting of sperm } \\
\text { cells in a semen sample based on the } \\
\text { chromosome they are carrying (can only } \\
\text { influence sex of embryo) }\end{array}$ & $\begin{array}{l}\text { Sex selective abortion is legally prohibited in most } \\
\text { countries of the world. Nevertheless, millions of } \\
\text { especially female foetuses are aborted annually } \\
\text { around the world. In countries like China, India and } \\
\text { Vietnam, obstetric ultrasound has contributed to } \\
\text { unprecedented sex ratios at birth as high as } 120 \text { boys } \\
\text { for every } 100 \text { girls. While sex selective abortion is } \\
\text { often considered to be a problem of the so-called } \\
\text { global South linked to son preference, sex selective } \\
\text { fertilization of gametes or implantation of embryos } \\
\text { (as opposed to abortion) is often described as "family } \\
\text { balancing" or "lifestyle" sex selection in the global } \\
\text { North. While prohibited in some countries, thousands } \\
\text { of cycles of MicroSort } \text { insemination and PGD for sex }_{\text {selective purposes are carried out each year globally. }}\end{array}$ \\
\hline $\begin{array}{l}\text { Selecting for a } \\
\text { healthy/normal child } \\
\text { (prevention of disease/disability) }\end{array}$ & $\begin{array}{l}\text { - Selective abortion of foetuses following } \\
\text { detection of "serious" fetal abnormality, } \\
\text { chromosomal disorder or genetic disease } \\
\text { - Selective implantation of only } \\
\text { unaffected/healthy embryos following in } \\
\text { vitro fertilization (IVF) and embryo } \\
\text { biopsy (PGD) } \\
\text { Sex selective fertilization of gametes } \\
\text { following the MicroSorting of sperm } \\
\text { cells in a semen sample based on the } \\
\text { chromosome they are carrying (can only } \\
\text { influence sex of embryo) in order to } \\
\text { avoid transmitting a sex-linked genetic } \\
\text { disease } \\
\text { Selective fertilization of gametes } \\
\text { following medical screening of gamete } \\
\text { donors to prevent transmission of } \\
\text { infectious or genetic disease }\end{array}$ & $\begin{array}{l}\text { Prenatal screening programmes have been routinized } \\
\text { throughout the world covering millions of women } \\
\text { (there are an estimated } 213 \text { million pregnancies } \\
\text { globally every year, not all are screened) involving } \\
\text { combinations of maternal serum screening, free foetal } \\
\text { DNA screening, obstetric ultrasound scans and } \\
\text { invasive prenatal diagnosis. Legislation varies with } \\
\text { some countries allowing for late-term abortions if a } \\
\text { "serious" condition is detected. Such terminations } \\
\text { remain controversial in many countries and there is } \\
\text { no consensus as to what conditions (if any) are } \\
\text { considered serious enough to warrant an abortion. } \\
\text { Following the detection of foetal abnormalities, } \\
\text { chromosomal disorders or genetic } \\
\text { diseases/conditions, hundreds of thousands of } \\
\text { pregnancies are terminated annually (legally and } \\
\text { illegally) around the world (there are an estimated } 45 \\
\text { million induced abortions globally every year, we } \\
\text { estimate between } 0.2-1 \% \text { of abortions are on grounds } \\
\text { of substantial risk that the child would be seriously } \\
\text { affected if the pregnancy is not terminated). } \\
\text { Thousands of cycles of Microsort }{ }^{\oplus} \text { insemination } \\
\text { and/or PGD are carried out around the world to } \\
\text { prevent transmission of a genetic disease. }\end{array}$ \\
\hline $\begin{array}{l}\text { Selecting for desired traits } \\
\text { (donor selection) }\end{array}$ & $\begin{array}{l}\text { Selective fertilization of gametes } \\
\text { following the choosing of a suitable } \\
\text { gamete donor based on available } \\
\text { information about donor health, eye } \\
\text { colour, hair colour, blood type, height, } \\
\text { intelligence, beauty, race/ethnicity, etc. } \\
\text { Selective implantation of embryos with } \\
\text { disabilities by parents with disabilities } \\
\text { (e.g. deafness or dwarfism) }\end{array}$ & $\begin{array}{l}\text { Sperm banks and egg brokers screen thousands of } \\
\text { potential gamete donors every year. Of these, } \\
\text { between } 10-20 \% \text { are selected as qualified donors } \\
\text { according to screening criteria. Legislation varies with } \\
\text { some countries prohibiting all gamete donation and } \\
\text { others allowing infertile couples, single women and/or } \\
\text { lesbian and gay couples to access donor gametes. } \\
\text { Studies have shown that infertile heterosexual } \\
\text { couples are mostly concerned with health and less } \\
\text { concerned with traits while gay couples, lesbian } \\
\text { couples and single women often select for traits that } \\
\text { are familiar to them and their families. Hundreds of } \\
\text { thousands of donor babies have been born } \\
\text { worldwide, the first major cohort of which (born in } \\
\text { the } 1980 \text { ) is now actively seeking out donor siblings } \\
\text { and their biological fathers or mothers. }\end{array}$ \\
\hline $\begin{array}{l}\text { Selecting for saviour siblings } \\
\text { (HLA matching) }\end{array}$ & $\begin{array}{l}\text { - Selective implantation of histologically } \\
\text { compatible embryos following in vitro } \\
\text { fertilization, embryo biopsy and HLA } \\
\text { (human leukocyte antigen) typing (using } \\
\text { PGD) in order to treat a sick sibling }\end{array}$ & $\begin{array}{l}\text { Hundreds of saviour siblings have been created using } \\
\text { PGD throughout the world starting in the United } \\
\text { States of America in 2000. Using PGD to create saviour } \\
\text { siblings remains controversial (because of concerns } \\
\text { about the welfare and instrumentalisation of the } \\
\text { saviour child) and not all countries allow it. }\end{array}$ \\
\hline
\end{tabular}

Table 0.1: Major forms of selective reproduction in the 21st century (see References for sources) 
This chapter is from Selective Reproduction in the $21^{\text {st }}$ Century, and the final (edited, revised and typeset) version can be found in the edited volume published by Palgrave Macmillan (2017).

Such technologies have become routine throughout the world, to an extent that the birth of the world's 5 millionth IVF baby was celebrated by the European Society of Human Reproduction and Embryology in July 2012. A string of ethnographies over the last two decades have shown how IVF is construed as a solution to the disruptions of infertility and can become a way of a life for many involuntarily childless couples as treatment appointments, drug regimens, oocyte retrievals and embryo transfers take over their daily lives with many couples opting for multiple cycles in the face of repeated failure (Franklin 1997; Becker 2000; Thompson 2005). We have also seen how the development and practice of ART comes to be shaped by local moralities as well as national aspirations and programmes in so-called pro-natalist countries like Egypt, Israel, India and China (Inhorn 2003; Kahn 2000; Handwerker 2002; Bharadwaj 2016; Wahlberg 2016). Finally, as couples are increasingly prepared to travel in pursuit of conception, social scientists have turned their attention towards the phenomenon of 'reproductive tourism' or 'reproductive travel' as involuntarily childless couples - 'reproductive exiles' - cross international borders as a way to circumvent local restrictions, seek better quality care or more affordable treatment (Inhorn \& Gürtin 2011; Inhorn 2015; Stockey-Bridge, this volume).

In recent years, similar ethnographic attention has been directed at what we term selective reproductive technologies (SRTs) (Gammeltoft \& Wahlberg 2014). It is important to distinguish between ARTs and SRTs, not least because of the differing objectives that are at stake. If "nature assisted' is a fitting caption for ARTs, then SRTs might be summarized as 'nature directed'. This is what Sarah Franklin and Celia Roberts were pointing to when contrasting IVF and preimplantation genetic diagnosis (PGD) in Born and Made. While both involve in vitro fertilisation, "the goal of IVF is a child, whereas the goal of PGD is, in a sense, the reverse, in that it is aimed at preventing some kinds of children being born" (Franklin \& Roberts 2006: 
This chapter is from Selective Reproduction in the $21^{\text {st }}$ Century, and the final (edited, revised and typeset) version can be found in the edited volume published by Palgrave Macmillan (2017).

161). ${ }^{2}$ The point being that, SRTs involve a decision not just to seek a viable pregnancy and a birth, but indeed to determine pregnancy outcome in very specific ways, which is to say by preventing or promoting the birth of specific kinds of children. Indeed SRTs can be thought of as a vote of no confidence against nature, as they do not so much stand in for natural biological processes as they seek to steer or obstruct these same processes. Social studies of ARTs have pointed to the importance of kinship and relatedness in explaining the uptake of such technologies as involuntarily childless couples go to great lengths to ensure that they have their own, genetically related children (Edwards et al. 1993). SRTs on the other hand, are not primarily playing out in a context of infertility. Couples who pursue the use of SRTs are typically not negotiating an inability to conceive and as a result are not primarily concerned with ensuring succession through genetically related offspring or realising a dream of having a family. Instead they orient themselves towards the future living of their families. When making selective reproductive decisions, families invariably engage with their futures in terms of different kinds of living that they might wish to avoid (e.g. living with cystic fibrosis or living 'only' with girls) or achieve (e.g. living with healthy children, raising a son) (see Wahlberg 2009). In these cases it is not that nature can't deliver, it is rather that nature cannot be left to its own devices.

Having distinguished between the two, we know of course that any proposed dividing line between ARTs and SRTs will always be blurred not least since techniques often overlap and since it is difficult to imagine any reproductive process devoid of attempts to influence pregnancy outcomes. We see this in the case of transnational surrogacy involving egg donors (see Stockey-Bridge, this volume) or in the IVF clinics which now attract both couples seeking to overcome infertility and couples seeking to prevent transmission of a hereditary disease through embryo biopsies and PGD (see Pavone \& Lafuente, this volume). Nevertheless, it is, as 
This chapter is from Selective Reproduction in the $21^{\text {st }}$ Century, and the final (edited, revised and typeset) version can be found in the edited volume published by Palgrave Macmillan (2017).

this book shows, analytically productive to distinguish between what might be thought of as two different reproductive schemas, namely 'helping hand' or assisted reproduction which aims to technologically overcome biological obstacles to reproduction on the one hand, and 'guiding hand' or selective reproduction which aims to technologically prevent or promote the birth of certain kinds of children on the other, that is to say between nature assisted and nature directed.

\section{Gametes, embryos, fetuses}

As we have already pointed out, selective reproduction is nothing new. But if we look at this reproductive schema today, we can see how, until only relatively recently, selective reproduction mainly took place at the two poles: either before fertilization (think of partner selection or sterilization) or following birth (think of infanticide or selective neglect). We say mainly because pregnancy of course has been subject to all kinds of taboos and advices aimed at generically or specifically influencing pregnancy outcomes for a very long time, just as induced abortion has been used to prevent transmission of traits to offspring. Nonetheless, it is fair to say that since the 1970s, following the birth of Louise Brown, the development of increasingly sophisticated biomedical technologies has allowed for selective reproductive practices to become more targeted. Not only has human reproduction been separated from sex, as already noted, the entire reproductive process has been parcelled out and fragmented using ever more specialized techniques related to insemination, fertilization, implantation, gestation, and birth. Gamete banks, medical/clinical genetics departments, IVF laboratories, prenatal clinics, abortion clinics, neonatal units and maternity wards are each involved in reproductive health care in different ways. Moreover, with the advent of cryopreservation in the latter half of the 20th century, each 
This chapter is from Selective Reproduction in the $21^{\text {st }}$ Century, and the final (edited, revised and typeset) version can be found in the edited volume published by Palgrave Macmillan (2017).

reproductive segment can be realized in different places (indeed on opposite sides of the world), using gametes from partners and/or donors (at times in combination with gestational surrogates) and at varied intervals (the record with frozen sperm is 25 years and legal requests for posthumous use of frozen gametes or embryos are increasing around the world). Reproduction, it is safe to say, has become transbiological, transtemporal and transnational in hitherto unimagined ways while introducing possibilities of selection at each step.

At the same time, this fragmentation of the reproductive process has introduced new reproductive sites, techniques, forms of expertise and dilemmas. SRTs comprise of specific laboratory and clinical techniques which facilitate the selective fertilisation of gametes, implantation of embryos or abortion of foetuses (see Box 1). Decisions about which gametes to fertilise, which embryos to implant or which foetuses to abort are explicitly wound up in ideas about the kinds of children that are desired or unwanted; ideas which in turn are inextricably bound to the kinds of societies within which selective reproduction is taking place. Prospective parents who engage with SRTs are not dealing with ways to overcome involuntary childlessness, rather they are involved in the planning of future family life.

In countries where gamete donation is allowed, sperm banks and egg agencies make selective decisions about which donors to accept by socially and medically screening them. Such screening practices are shaped by cultural values and social norms around notions of what a 'high quality' or 'good quality' donor might be, often times reifying eugenicist notions of positive selection (see Martin, this volume). These values and norms not only shape their recruitment and screening practices, they are also actively mobilised in marketing campaigns and information provided to prospective parents which include infertile couples, single women and lesbian couples (albeit with differential access in different countries depending on legislation) 
This chapter is from Selective Reproduction in the $21^{\text {st }}$ Century, and the final (edited, revised and typeset) version can be found in the edited volume published by Palgrave Macmillan (2017).

(see Stockey-Bridge, this volume). Moreover, couples with a known sex-linked genetic disease in their family may choose to Microsort ${ }^{\circledR}$ their sperm prior to insemination or in vitro fertilisation as a means of sex selecting in order to avoid transmitting that disease. Microsort ${ }^{\circledR}$ has also been marketed as a potential means for sex selective 'family balancing' (see Bhatia, this volume). In selectively deciding which gametes to use, prospective parents are confronted with questions about which kinds of children are desired or unwanted for them as they go about planning their future family lives.

One of the consequences of routinized infertility treatment has been the bioavailability of embryos in vitro (cf. Cohen 2007). While these human embryos were initially produced in the clinic to identify those embryos considered to be the most viable for infertile couples seeking to achieve pregnancy, since 1990, increasing numbers of couples have chosen to pursue IVF cycles in order to allow embryologists to biopsy resulting embryos. Such biopsies provide geneticists with access to a potential child's DNA, allowing for genetic testing prior to implantation, which is known as preimplantation genetic diagnosis (PGD). PGD was developed to help families with a known hereditary disease to avoid commencing an affected pregnancy, thereby hopefully alleviating them of the difficult decision of whether or not to terminate a pregnancy. As such, PGD is a form of family planning that has become an option for some so-called carriers of a genetic mutation who want to avoid passing on a disease that lies dormant in their genes. More recently, PGD has also been used as a means to secure the birth of a histologically compatible child (a so-called saviour sibling) who can provide blood and tissue samples for therapeutic use in a sick sibling suffering from, for example, sickle cell anaemia or $\beta$-thalassaemia (Dobson 2003). Finally, PGD has emerged as a technique to facilitate 'lifestyle' sex selection or 'family balancing' for some couples. And so, just like in the case of gamete sorting, couples who 
This chapter is from Selective Reproduction in the $21^{\text {st }}$ Century, and the final (edited, revised and typeset) version can be found in the edited volume published by Palgrave Macmillan (2017).

\author{
Four important milestones in the development of SRTs globally
}

Seeing the foetus - ever since ultrasound technology was first used for foetal head measurements in the 1960s, its ability to detect gender and physical abnormalities has propelled it to universal use in prenatal care. Sex selection is by far the most common form of selective reproduction today and the correlation between growing ultrasound availability and the skewing of sex-ratios in countries like China, India and Vietnam is dramatic (UNFPA 2012). Moreover, foetal anomaly scans halfway through a pregnancy have become routine throughout the world to detect and confirm diagnoses of anencephaly, spina bifida, Edward's syndrome and more, generating dilemmas for parents as they consider whether to continue or terminate a pregnancy.

Decoding the foetus - the development of reproductive genetics has had a profound effect on antenatal care. While ultrasound technologies are becoming ever better at seeing the foetus they cannot tell parents anything about their foetus's genetic makeup which is hidden away in its DNA. As such, ever since Fuchs and Riis in 1956 reported being able to determine the sex of a foetus after having collected amniotic fluid from pregnant women (Fuchs \& Riis 1956), clinicians have been looking for safe and reliable ways of getting access to a foetus's DNA. Amniocentesis, chorionic villus sampling and most recently free foetal DNA testing have each been developed for this purpose and have become standard offers for women during antenatal care. Once samples of a foetus's DNA are available, they can be subject to a battery of genetic tests and screens to determine whether the foetus has a rare genetic disease, Down's syndrome or other chromosomal disorder. Concomitant screening procedures have also been developed to help identify those couples considered at risk who may then opt for an invasive procedure to get access to foetal DNA. Most recently, isolation of free foetal DNA from an expecting woman's serum has made non-invasive prenatal testing a reality.

Avoiding transmission - family disease history has long played a role in reproductive decision making as families have sought to avoid passing on debilitating conditions such as Huntington's disease or aggressive forms of cancer to their children. In the post-World War II period, genetic counselling emerged as a particular specialisation in hospitals aimed at providing couples with a known (or suspected) hereditary disease with information about how inheritance works and what options they have when planning a pregnancy. Options may include carrier testing to see whether the man, woman or both carry a mutation of a genetic disease followed by gamete donation, preimplantation genetic diagnosis (PGD) of embryos or prenatal genetic testing of foetuses. Genetic counsellors are trained to be 'nondirective' as they encourage couples to make their own decisions about whether to begin, continue or terminate a pregnancy.

Sorting gametes and embryos - one of the important consequences of IVF technology has been displacement of the fertilisation process from the womb to the laboratory. No longer only brought together through sexual intercourse, gametes can now be retrieved after which they can be prepared, sorted, cryopreserved and eventually fertilised. Once fertilised, clinicians are faced with the decision of which resulting embryos (and how many) to implant into the woman. A number of selective practices have emerged in the lab as a result, each of which is used to prevent or promote the birth of certain kinds of children. Developed in the 1970s, Microsorting ${ }^{\circledR}$ 'separates the sperm cells in a semen sample based on the chromosome they are carrying... result[ing] in samples containing significantly increased percentages of sperm that are carrying the desired (X or Y) chromosome' (MicroSort 2013). In this way, couples can significantly increase their chances of conceiving a boy or a girl or avoid transmitting a sex-linked genetic disease by inseminating sorted sperm or by using sorted sperm in conjunction with IVF. Similarly, gamete banks and brokers tend to select 'good quality' donor candidates with traits considered desirable by recipients. Since 1990, preimplantation genetic diagnosis (PGD) clinics have carried out genetic tests on successfully fertilised embryos by taking a cell biopsy from each embryo as a way to decide: which affected (or mutation carrying) embryos should not be implanted in order to avoid transmission of hereditary disease; which histologically compatible embryos should be chosen for implantation to produce a so-called saviour sibling; or which embryo should be chosen for implantation to secure the birth of a boy or a girl. 
This chapter is from Selective Reproduction in the $21^{\text {st }}$ Century, and the final (edited, revised and typeset) version can be found in the edited volume published by Palgrave Macmillan (2017).

\section{Box 1}

selectively decide which embryos to implant following embryo biopsies and genetic tests are confronted with questions about which kinds of children are desired (e.g. a girl or an HLA-match for a sick sibling) or unwanted (e.g. a child with cystic fibrosis or Huntington's disease) as they attend to their current families while imagining their future family lives.

Throughout the world, pregnancies have come to be the object of various forms of medicalised surveillance through routine prenatal care which can involve ultrasound scans, maternal serum tests as well as amniocentesis or chorionic villus sampling. The goal of this surveillance is to monitor the health of women and foetuses during gestation as a way to ensure safe and healthy births. With the global routinization of ultrasound scans as well as prenatal risk assessments in the closing decades of the $20^{\text {th }}$ century, one can say that the majority of pregnancies have become potentially selective - or 'tentative' in Barbara Rothman's (1993) phrase - as prospective parents grapple with societal expectations and their own convictions about which kinds of children are desired (e.g. a son) or unwanted (e.g. a child with Down's Syndrome) as they prepare for an approaching birth. Termination of pregnancy - whether for sex selective reasons (millions of pregnancies have been estimated to have been terminated to avoid the birth of a girl) or to prevent the birth of a child with a serious disease (thousands of pregnancies are terminated around the world each year following prenatal screening, testing and diagnosis) - is the most ubiquitous form of selective reproduction in the $21^{\text {st }}$ century. The surveillance and, in some cases, ensuing terminations of pregnancies are, existing research shows, often shrouded in deep ambivalence, as pregnant women, relatives, and health care providers agonize over the potential or actual - life-and-death decisions that SRTs confront them with (see Rapp 1999, Gammeltoft 2014, Trần, this volume). 
This chapter is from Selective Reproduction in the $21^{\text {st }}$ Century, and the final (edited, revised and typeset) version can be found in the edited volume published by Palgrave Macmillan (2017).

\section{Tracking routes of routinization}

Any attempt to empirically address the unfolding routinization of SRTs globally, as this book sets out to do, must attend to a multitude of problematics. As medical technologies, SRTs must traverse the continuum from experimental technology to standard of care to become routinized (Koenig 1988), a process that is unique to every country. SRTs have tended to go through variegated patterns of acceptance in different countries: from pioneering 'breakthroughs', at times followed by periods of concern and resistance, then regulation and eventually routinization as particular procedures are rolled out and made available (Wahlberg 2016). Consequently, we propose four important empirical routes to studying SRTs in the 21 st century. First of all, as we have seen, there are a range of techniques. SRTs comprise a plethora of specialized techniques such as amniocentesis, ultrasound scans, sperm sorting, preimplantation genetic diagnosis and carrier testing - each of which zooms in on a particular segment of the reproductive process. Each technique can be (and indeed have been by many scholars) studied in terms of its history, social life and/or social impact (Rapp 2000; Franklin \& Roberts 2006; Gammeltoft 2014). Once standardized, such techniques can be rolled out in the form of routine prenatal care or national screening programmes. Among the techniques that will be explored in the following chapters are sperm-sorting, egg harvesting, preimplantation genetic diagnosis, maternal serum screening and ultrasound screening.

Secondly, as noted earlier, one of the consequences of the fragmentation of the reproductive process has been the emergence of specialised sites dealing with particular aspects of reproduction. It is in these sites that we as social scientists often must negotiate access and carry 
This chapter is from Selective Reproduction in the $21^{\text {st }}$ Century, and the final (edited, revised and typeset) version can be found in the edited volume published by Palgrave Macmillan (2017).

out our fieldwork and interviews, ranging from sperm banks to clinical genetics units, IVF labs, prenatal clinics, abortion clinics and labour wards, not to mention the homes and communities of all those couples who engage with SRTs. To understand routinization we need to visit the places in which certain diagnostic and screening offers operate on a daily basis, witnessing the daily grind while analysing the interactions between professionals, techniques and couples.

Contributors to this volume have carried out research in egg agencies, IVF clinics, prenatal care units, ultrasound clinics as well as pregnancy termination units.

Thirdly, it is arguably the people that engage with SRTs that are the most important constituents in understanding how SRTs come to be routinized and globally widespread. The field of selective reproductive technologies is filled with a myriad of choreographies, decisionmaking processes, evaluations and deliberations. In researching SRTs we meet its users in the form of 'prospective parents', 'intending parents', 'expecting couples', 'pregnant women' or 'families' who at times will choose to use a gamete donor or surrogate mother. To understand how SRTs are experienced and incorporated into individual family planning strategies - whether in accordance or in conflict with dominant cultural values and social norms - it is essential that social scientists spend time with those who make use of SRTs. We also meet SRT practitioners such as clinicians, nurses, geneticists, sonographers, midwives, gamete brokers, gynaecologists, obstetricians, nurses and embryologists who go about ensuring that SRT services are provided to users, often in so-called resource poor settings. Perhaps inevitably, considering the controversies that surround selective reproduction, social scientists also often seek out policymakers, government officials, lawyers and ethicists in their countries of study as part of their efforts to understand how SRTs are normalized in particular places and at particular historical moments. It 
This chapter is from Selective Reproduction in the $21^{\text {st }}$ Century, and the final (edited, revised and typeset) version can be found in the edited volume published by Palgrave Macmillan (2017).

is these users, practitioners and regulation makers that each of us has talked to and spent time with when studying selective reproduction in the 21 st century in different parts of the world.

Finally, empirical engagement with SRTs will almost always lead not only to regulation makers but also to the laws, regulations and guidelines (as documents) which circumscribe the availability and intended use of SRTs. Selective reproduction is an ethically and emotionally charged field of practice governed not only by national laws such as the Embryo Protection law in Germany or the Law on Maternal and Infant Healthcare in China, but also by a host of procedures, guidelines, codes, contracts, forms, etc. aimed at ensuring acceptable ('appropriate' and 'lawful') use of SRTs in clinical settings through Good Clinical Practices, Good Laboratory Practices as well as ethical guidelines. Moreover, nation states invest heavily in the deployment of SRTs through screening programmes and health delivery systems, not least with the controversial (at times explicit, at others implicit) aim of reducing congenital malformations and hereditary disease. It is therefore virtually impossible, as we will see, to study SRTs today without familiarizing if not immersing ourselves into such regulatory debates and texts.

Taken together, these techniques, sites, people and regulations form selective reproductive assemblages, infrastructures or complexes (cf. Collier \& Ong 2007; Inhorn 2015; Larkin 2013; Vertommen 2016; Wahlberg 2016) which are always particular to the different countries, economies, cultures and societies within which we study SRTs. As Wahlberg (2016) has argued, when it comes to medical technologies, routinization is a socio-historical process whereby certain forms of medical technology come to be (re-)produced and entrenched within particular juridical, medical, social, economic, cultural and institutional configurations. It also entails a daily grind of practices through which certain medical technologies are rolled out and become an established and habituated part of health delivery, which is to say a standard of care provided in a 
This chapter is from Selective Reproduction in the $21^{\text {st }}$ Century, and the final (edited, revised and typeset) version can be found in the edited volume published by Palgrave Macmillan (2017).

fixed setting. And finally, routinization suggests a gradual take up and acceptance of a medical technology such that it becomes a normalised part of daily life, in the sense that it is available to and used by its intended users in a routine manner, albeit surrounded by all manner of socioeconomic or cultural barriers. In the chapters that follow, we will learn how SRTs came to be routinized in different parts of the world from Denmark to Spain, Vietnam, India, Taiwan, Australia and USA.

\section{Tracking the economic and political forces underpinning routinization}

Across the globe, SRTs are located at a convergence of political and economic forces. In some countries, national governments define SRTs as political tools, mobilizing new technologies for selective reproduction in overt efforts to enhance "population quality" (see Shih, this volume). Seeking to prevent the birth of children with disabilities, the governments of China and Vietnam for instance are actively encouraging pregnant women to make use of prenatal screening and testing technologies. A strong and healthy population, government authorities inform people, is a precondition for national stability and welfare (Zhu 2013; Greenhalgh \& Winckler 2005;

Gammeltoft 2014). In other countries, most notably in Europe and the US, the spectre of $20^{\text {th }}$ century eugenics continues to haunt present-day reproductive policies, compelling state authorities to frame selective reproductive decisions as matters of personal preference and choice rather than as matters of demography. SRTs are not, government documents emphasize, introduced to serve demographic purposes; rather, they serve as medical means by which citizens' capacities to make their own reproductive choices can be enhanced (Schwennesen \& Koch 2009; Meskus 2009). As much research has shown, however, individual reproductive choices are 
This chapter is from Selective Reproduction in the $21^{\text {st }}$ Century, and the final (edited, revised and typeset) version can be found in the edited volume published by Palgrave Macmillan (2017).

always formed by the socio-political contexts within which they are made, guided by powerful societal norms, values, and expectations (see Heinsen, this volume; Shih, this volume; Trần, this volume; Rapp 1999). This is the case also in social settings where official health care practice guidelines emphasize balanced information and individual choice: such information provision tends to be carried by particular normative demands and expectations, pushing people in certain decision-making directions. Consequently, some critics have characterized $21^{\text {st }}$ century selective reproduction as a 'laissez-faire,' 'back-door,' 'neo,' or 'flexible' eugenics (Duster 2003; Taussig et al. 2003; Lock 2007).

Besides political forces, economic forces also drive the introduction and routinization of SRTs. Within public health care systems, the introduction of state-funded programs for pregnancy screening and testing are often based on cost-benefit calculations assessing the costs saved if fewer children are born with disabilities (Schwennesen et al 2009). Some countries offer couples access to publicly funded carrier testing and, if a genetic disposition is found, access to publicly funded PGD. Yet these offers cover only certain selected conditions, and decisions regarding which prospective parents should be offered access to these technologies rely on calculations assessing the economic gains attained if the birth of a child with this particular condition is averted. The assumed societal resource implications are, in other words, often the subtle subtext when public sector SRTs are offered. Due to the sinister history of $19^{\text {th }}$ century eugenics, however, such underlying economic rationales are often downplayed in official documents and policy guidelines, perhaps particularly in Europe where the eugenics movement had the most disastrous consequences (cf. Erikson 2003, Koch 2006).

When selective reproduction takes place in the private health care sector, economic rationales play important roles too. The parcelling out of reproductive processes described above has 
This chapter is from Selective Reproduction in the $21^{\text {st }}$ Century, and the final (edited, revised and typeset) version can be found in the edited volume published by Palgrave Macmillan (2017).

entailed novel possibilities for commercialization and commodification: from being intimate and integral parts of individual bodies, human eggs and sperm have changed character and can now be extracted, stored, and circulated in national and transnational capitalist circuits. In the reproductive markets that this has generated, some gametes hold higher value than others, offering the prospect of considerable economic profit (e.g. Martin, this volume; Pavone \& Lafuente, this volume; Almeling 2009; Pollock 2003). It is probably no coincidence that 'sperm banks' are described through metaphors derived from the financial world. As the bedrock of capitalism, banks facilitate markets, the notion of 'sperm bank' pointing us to the ways in which human bodies and their reproductive capacities are being turned into property in the $21^{\text {st }}$ century. These processes are evident also in markets for babies. The increasing access to surrogacy services in countries around the world entails new possibilities for economic gain; cross-border surrogacy is by now a multi-billion dollar global industry (Deonandan 2015). As donor gamete selection is often involved in these arrangements, although surrogacy is primarily an assisted reproductive technology, it nonetheless can have its 'selective moments', as Stockey-Bridge shows us in Chapter 7. Further, in many countries with privatized health care systems, prenatal screening and testing are important sources of revenue for health care providers, and their economic interests may therefore fuel a technology's routinization (cf. Gammeltoft and Nguyen 2007). Selective reproduction is, in short, lucrative business in many respects, and as such a focal point of numerous economic interests. The biomedical research and technological development that precedes the launch of new SRTs will, as Bhatia's (this volume) work in a Euro-American context exemplifies, often take place in an orientation towards a given technology's marketability and economic potential. 
This chapter is from Selective Reproduction in the $21^{\text {st }}$ Century, and the final (edited, revised and typeset) version can be found in the edited volume published by Palgrave Macmillan (2017).

Economic calculations are, however, not restricted to the domains of states and markets; they are also made within domestic worlds. When individuals and couples resort to SRTs, personal assessments of the economic burdens and benefits that the birth of a particular kind of child will entail often contribute to shaping their motivations; users of SRTs are often engaged in active forms of planning or 'reproductive accounting' (Franklin and Roberts 2006: 164; Shih, this volume). In many cultures, a male child is expected to be of long-term economic gain to his parents, while a female child is considered as a cost (see Trần, this volume; Khanna 2010). The capacity to influence the sex of one's children can therefore play an important role in domestic economic calculations, not least in low-income societies. Similarly, across the globe, prospective parents often express concern regarding the financial burdens that the birth of a disabled child can be expected to place on their household economy (Gammeltoft 2014; Kohrman 2005). Even in affluent welfare societies, parents-to-be must weigh the assumed needs of particular potential children against the care that they expect to be able to provide given the economic means they have at hand. Fears and anxieties regarding their own capacities to care adequately for their child often seem to push prospective parents towards the uptake of SRTs (Rapp 1999; Gammeltoft 201; Heinsen, this volume). As we will see in the chapters that follow, these various forms of reproductive accounting shape the ways in which SRTs come to be viewed, made available, and used in specific countries and settings.

Possibilities for SRT uptake are, however, unevenly distributed. While some technologies such as $2 \mathrm{D}$ ultrasounds - are relatively low-cost and therefore generally accessible, access to other technologies, such as PGD, requires considerable economic means. Such uneven distributions are also evident in the moral separation of sex selective abortion (associated most often with countries of the global South) from PGD-enabled 'lifestyle sex selection' which is 
This chapter is from Selective Reproduction in the $21^{\text {st }}$ Century, and the final (edited, revised and typeset) version can be found in the edited volume published by Palgrave Macmillan (2017).

marketed by IVF clinics in the US (cf. Trần, this volume \& Bhatia, this volume). For most people in the contemporary world, access to SRTs is not a given. Economic stratification shapes not only people's access to technology but also determines how they are positioned in relation to it: some individuals and couples are placed in economic positions that enhance their chances of realizing their reproductive desires, while others - such as women in low-income countries who carry other people's children in their wombs in surrogacy arrangements - live in situations of economic vulnerability that expose them to considerable reproductive health risks.

\section{Conclusion: ethnographies of SRTs}

The cultural, social and economic rationales that underlie the spread of SRTs have raised criticism from various quarters. Pointing to the alternative ways in which societal resources could be used, disability rights activists have argued that the promotion of SRTs tends to rest on and reinforce a reduction of the value of disabled lives. In Tom Shakespeare's words: "The drive to use genetic and obstetric techniques to remove disabled people from the population fails to consider the millions of people developing impairments as a result of accident or disease during the life-course. Resources would be better spent on creating an inclusive and barrier-free society, and promoting the civil rights and independent living of disabled people. Society should value disabled people, alongside all human life" (1998: 678-79). In a similar vein, women's health activists have criticised the subtle or not-so-subtle ways in which pregnant women are placed under pressure to conform to unspoken health systems expectations and opt for a pregnancy termination in case a child-to-be is found to be anomalous. Marsha Saxton, for instance, writes: "Those who advocate selective abortion to alleviate the suffering of children may often raise that 
This chapter is from Selective Reproduction in the $21^{\text {st }}$ Century, and the final (edited, revised and typeset) version can be found in the edited volume published by Palgrave Macmillan (2017).

cornerstone of contemporary political rhetoric, cost benefit. Of course, cost-benefit analysis is not woman-centered, yet women can be directly pressured or subtly intimidated by both arguments. It may be difficult for some to resist the argument that it is their duty to 'save scarce health care dollars,' by eliminating expensive disabled children. But those who resist these arguments believe the value of a child's life cannot be measured in dollars" (1998: 383; see also Lippman 1999).

Criticism has also been raised of the commercialization and manipulation of human childbearing that SRTs allow for. The concept of 'designer baby' captures ethical anxieties regarding what kind of society we are moving towards if increasing numbers of prospective parents are enabled to select for specific traits in their children, 'buying' the kinds of babies that they want. To date, however, such a brave new world of perfectly designed offspring still seems far away, as the contingencies involved in human childbearing appear to continue to surpass our capacities for technological manipulation (Franklin \& Roberts 2006).

Against the backdrop of these important social and ethical debates, the task that we have set ourselves in this volume is empirical: What techniques have been developed to facilitate selective reproduction in recent decades? How are SRTs being rolled out and made available within different regulatory frameworks? How do people living in different cultural settings perceive, respond to, and make use of the new possibilities for selective reproduction that they are offered? Addressing the social and ethical questions that selective reproduction raises requires, we believe, concrete and critical insights into the ways in which new technologies for selective reproduction operate on the ground as people weave these technologies into family lives, clinical worlds, and political imaginaries. Through ethnographic studies conducted across the world, this volume seeks to provide such insights, thereby offering new and research-based 
This chapter is from Selective Reproduction in the $21^{\text {st }}$ Century, and the final (edited, revised and typeset) version can be found in the edited volume published by Palgrave Macmillan (2017).

contributions to the ethical and political debates that selective reproduction will continue to generate in years to come.

\section{References}

Becker, Gay. 2000. The Elusive Embryo: How Men and Women Approach New Reproductive Technologies. Berkeley: University of California Press.

Bharadwaj, Aditya. 2016. Conceptions: Infertility and Procreative Technologies in India. Berghahn Books.

Cohen, Lawrence. 2007. Operability, Bioavailability, and Exception. In Global Assemblages, edited by Aihwa Ong and Stephen J. Collier, 79-90. Blackwell Publishing Ltd.

Collier, Stephen J., and Aihwa Ong. 2007. Global Assemblages Anthropological Problems. In Global Assemblages, edited by Aihwa Ong and Stephen J. Collier, 3-21. Blackwell Publishing Ltd.

Deonandan, Raywat. 2015. Recent trends in reproductive tourism and international surrogacy: ethical considerations and challenges for policy. Risk Management and Healthcare Policy 8:111-119.

Dobson, R. (2003). "Saviour sibling" is born after embryo selection in the United States. British Medical Journal, 326(7404): 1416.

Duster T. 2003. Backdoor to Eugenics. New York: Routledge

Edwards, Jeanette, Sarah Franklin, Eric Hirsch, Frances Price, and Marilyn Strathern. 1999. Technologies of Procreation: Kinship in the Age of Assisted Conception. $2^{\text {nd }}$ edition. New York: Routledge.

Franklin, Sarah. 1997. Embodied Progress: A Cultural Account of Assisted Conception. London ; New York: Routledge.

Franklin, Sarah, and Celia Roberts. 2006. Born and Made: An Ethnography of Preimplantation Genetic Diagnosis. Princeton: Princeton University Press. 
This chapter is from Selective Reproduction in the $21^{\text {st }}$ Century, and the final (edited, revised and typeset) version can be found in the edited volume published by Palgrave Macmillan (2017).

Gammeltoft, Tine M. 2014. Haunting Images: A Cultural Account of Selective Reproduction in Vietnam. Berkeley: University of California Press.

Gammeltoft T, Nguyen TTH. 2007. Fetal conditions and fatal decisions: ethical dilemmas in ultrasound screening in Vietnam. Social Science \& Medicine 64:2248-59.

Gammeltoft, Tine M., and Ayo Wahlberg. 2014. "Selective Reproductive Technologies.” Annual Review of Anthropology 43 (1): 201-16.

Greenhalgh, Susan, and Edwin A. Winckler. Governing China's Population: from Leninist to Neoliberal Biopolitics. Stanford University Press, 2005.

Handwerker, Lisa. 2002. The Politics of Making Modern Babies in China: Reproductive Technologies and the "New" Eugenics. In Infertility Around the Globe: New Thinking on Childlessness, Gender, and Reproductive Technologies, edited by Marcia Claire Inhorn and Frank van Balen, 298-314. University of California Press.

Inhorn, Marcia C. 2003. Local Babies, Global Science: Gender, Religion and In Vitro Fertilization in Egypt. New York: Routledge.

Inhorn, Marcia C. 2015. Cosmopolitan Conceptions: IVF Sojourns in Global Dubai. Durham: Duke University Press.

Inhorn, Marcia C., and Zeynep B. Gürtin. 2011. Cross-border reproductive care: a future research agenda. Reproductive Biomedicine Online 23(5): 665-676.

Kahn, Susan Martha. 2000. Reproducing Jews: A Cultural Account of Assisted Conception in Israel. Durham: Duke University Press Books.

Khanna SK. 2010. Fetal/Fatal Knowledge: New Reproductive Technologies and FamilyBuilding Strategies in India. Belmont: Wadsworth Cengage Learning.

Kohrman, Matthew. 2005. Bodies of difference: Experiences of disability and institutional advocacy in the making of modern China. Berkley: University of California Press.

Koch, Lene. 2006. Eugenic Sterilisation in Scandinavia. The European Legacy, 11(3): 299-309. Larkin, Brian. 2013. The Politics and Poetics of Infrastructure. Annual Review of Anthropology 42 (1): 327-43.

Lippman, Abby. 1999. Embodied knowledge and making sense of prenatal diagnosis. Journal of Genetic Counseling 8(5):255-274. 
This chapter is from Selective Reproduction in the $21^{\text {st }}$ Century, and the final (edited, revised and typeset) version can be found in the edited volume published by Palgrave Macmillan (2017).

Lock M. 2007. Genomics, laissez-faire eugenics, and disability. In Disability in Local and Global Worlds, edited by B Ingstad, SR Whyte, pp. 189-211. Berkeley: University of California Press.

Meskus, Mianna. 2009. Governing risk through informed choice: Prenatal testing in welfarist maternity care. In Contested Categories: Life Sciences in Society. Edited by Susanne Bauer \& Ayo Wahlberg, Ashgate.

Microsort.2013.

Nuffield Council. 2006. Critical care decisions in fetal and neonatal medicine: ethical issues. London: Nuffield Council on Bioethics.

Rapp, Rayna. 1999. Testing Women, Testing the Fetus: The Social Impact of Amniocentesis in America. New York: Routledge.

Rothman, Barbara Katz. 1993. The Tentative Pregnancy: How Amniocentesis Changes the Experience of Motherhood. WW Norton \& Company.

Saxton, Marsha. 1998. Disability rights and selective abortion. In Abortion Wars: A Half Century of Struggle 1950-2000, edited by : Rickie Solinger, pp. 374-394. Berkeley: University of California Press.

Schwennesen, Nete \& Lene Koch. 2009. Calculating and visualising life: Matters of fact in the context of prenatal risk assessment. In Contested Categories: Life Sciences in Society. Edited by in Susanne Bauer \& Ayo Wahlberg. Surrey: Ashgate, pp. 69-87.

Schwennesen, Nete, Lene Koch and Mette Nordahl Svendsen. 2009. Practising informed choice: decision-making and prenatal risk assessment - the Danish experience. In Disclosure Dilemmas: Ethics of Genetic Prognosis After the 'Right to Know/Not to Know' Debate, edited by C. Rehman-Sutter and H. Müller. Surrey: Ashgate.

Shakespeare, Tom. 1998. Choices and rights: eugenics, genetics, and disability equality. Disability \& Society 13(5):665-681.

Strathern, Marilyn. 1992. Reproducing the Future: Anthropology, Kinship, and the New Reproductive Technologies. New York: Routledge.

1998. Surrogates and Substitutes. In The Politics of Postmodernity, edited by James Good and Irving Velody. Cambridge: Cambridge University Press. 
This chapter is from Selective Reproduction in the $21^{\text {st }}$ Century, and the final (edited, revised and typeset) version can be found in the edited volume published by Palgrave Macmillan (2017).

Svendsen, Mette Nordahl. 2014. Selective Reproduction: Social and Temporal Imaginaries for Negotiating the Value of Life in Human and Animal Neonates. Medical Anthropology Quarterly 29(2): 178-195.

Taussig Karen Sue, Rayna Rapp and Deborah Heath. 2003. Flexible eugenics: technologies of self in the age of genetics. In Genetic Nature/Culture: Anthropology and Science Beyond the Two-Culture Divide, edited by AH Goodman, D Heath, MS Lindee, pp. 58-76.

Berkeley: University of California Press

Thompson, Charis. 2007. Making Parents: The Ontological Choreography of Reproductive Technologies. Cambridge, MA: The MIT Press.

Wahlberg, Ayo. 2009. Serious Disease as Kinds of Living. In Contested Categories: Life Sciences in Society, edited by Susanne Bauer and Ayo Wahlberg, 89-112. Farnham: Ashgate.

_ 2016. "The Birth and Routinization of IVF in China." Reproductive Biomedicine \& Society Online. 2: 97-107.

Zhu, Jianfeng. 2013. Projecting potentiality. Understanding maternal serum screening in contemporary China. Current Anthropology 54(S7):S36-44

\section{$\underline{\text { Sources for Table 1: }}$}

Almeling, R. (2011). Sex Cells: The Medical Market for Eggs and Sperm. Berkley: University of California Press.

Baruch S, Kaufman D, Hudson KL. (2008).Genetic testing of embryos: practices and perspectives of US in vitro fertilization clinics. Fertility \& Sterility 89(5):1053-8.

Calhaz-Jorge, C., de Geyter, C., Kupka, M. S., de Mouzon, J., Erb, K., Mocanu, E., ... \& Gliozheni, O. (2016). Assisted reproductive technology in Europe, 2012: results generated from European registers by ESHRE. Human Reproduction 31(8):1638-52.

Chandrasekharan, S., Minear, M. A., Hung, A., \& Allyse, M. A. (2014). Noninvasive Prenatal Testing Goes Global. Science Translational Medicine, 6(231): 15.

de Graaf, G., Buckley, F., \& Skotko, B. G. (2015). Estimates of the live births, natural losses, and elective terminations with Down syndrome in the United States. American Journal of Medical Genetics Part A, 167(4), 756-767. 
This chapter is from Selective Reproduction in the $21^{\text {st }}$ Century, and the final (edited, revised and typeset) version can be found in the edited volume published by Palgrave Macmillan (2017).

De Rycke, M., Belva, F., Goossens, V., Moutou, C., SenGupta, S. B., Traeger-Synodinos, J., \& Coonen, E. (2015). ESHRE PGD Consortium data collection XIII: cycles from January to December 2010 with pregnancy follow-up to October 2011. Human Reproduction, 30(8), 1763-1789.

Department of Health and National Statistics 2008. Abortion Statistics, England and Wales: 2007. Statistical Bulletin, 2008(1).

Dobson, R. (2003). "Saviour sibling" is born after embryo selection in the United States. British Medical Journal, 326(7404): 1416.

Ekelund, C. K., Petersen, O. B., Skibsted, L., Kjærgaard, S., Vogel, I., \& Tabor, A. (2011). First $\square$ trimester screening for trisomy 21 in Denmark: implications for detection and birth rates of trisomy 18 and trisomy 13. Ultrasound in Obstetrics \& Gynecology, 38(2): 140144.

Ginsburg, E. S., Baker, V. L., Racowsky, C., Wantman, E., Goldfarb, J., \& Stern, J. E. (2011). Use of preimplantation genetic diagnosis and preimplantation genetic screening in the United States: a Society for Assisted Reproductive Technology Writing Group paper. Fertility and Sterility, 96(4): 865-868.

Human Fertilisation \& Embryology Authority. 2014. Egg and sperm donation in the UK: 2012 2013. London: HFEA

Kahraman, S., Beyazyurek, C., Yesilipek, M. A., Ozturk, G., Ertem, M., Anak, S., ... \& Slavin, S. (2014). Successful haematopoietic stem cell transplantation in 44 children from healthy siblings conceived after preimplantation HLA matching. Reproductive Biomedicine Online, 29(3): 340-351.

Karabinus, David S., Donald P. Marazzo, Harvey J. Stern, Daniel A. Potter, Chrispo I. Opanga, Marisa L. Cole, Lawrence A. Johnson, and Joseph D. Schulman. "The effectiveness of flow cytometric sorting of human sperm (MicroSort@) for influencing a child's sex." Reproductive Biology and Endocrinology 12, no. 1 (2014): 1.

Martin, L. J. (2014). Reproductive Tourism in the United States. Taylor \& Francis.

Sedgh, G., Bearak, J., Singh, S., Bankole, A., Popinchalk, A., Ganatra, B., ... \& Johnston, H. B. (2016). Abortion incidence between 1990 and 2014: global, regional, and subregional levels and trends. The Lancet. 388(10041): 258-67 
This chapter is from Selective Reproduction in the $21^{\text {st }}$ Century, and the final (edited, revised and typeset) version can be found in the edited volume published by Palgrave Macmillan (2017).

Sedgh, G., Singh, S., \& Hussain, R. (2014). Intended and unintended pregnancies worldwide in 2012 and recent trends. Studies in Family Planning, 45(3): 301-314.

Skotko, B. G. (2009). With new prenatal testing, will babies with Down syndrome slowly disappear? Archives of Disease in Childhood, 94(11): 823-826.

Sun, H. Y., Gu, M. J., Sun, Y. Y., Wang, S. Q., Liu, Z. L., Zhang, Z. X., ... \& Wang, Z. J. (2013). [Analysis of the pregnancy outcomes of 13723 tubes of sperm specimens from the sperm bank]. Zhonghua nan ke xue= National Journal of Andrology, 19(9): 798-801.

UNFPA. 2012. Sex Imbalances at Birth: Current Trends, Consequences and Policy Implications. New York: UNFPA.

Vassy, Carine. 2006. From a genetic innovation to mass health programmes: the diffusion of Down's syndrome prenatal screening and diagnostic techniques in France. Social Science \& Medicine 63(8): 2041-2051.

Vassy, C., Rosman, S., \& Rousseau, B. (2014). From policy making to service use. Down's syndrome antenatal screening in England, France and the Netherlands. Social Science \& Medicine, 106, 67-74.

Vertommen, S., (2016). From the pergonal project to Kadimastem: A genealogy of Israel's reproductive-industrial complex. BioSocieties, doi:10.1057/biosoc.2015.44

\section{Endnotes}

\footnotetext{
${ }^{1}$ It should be noted that developments in critical care of premature babies have in recent years raised numerous ethical questions around how decisions should be made about which (if any) premature babies doctors and parents should 'let die', not least because of concerns about the future health-related quality of life of the child if the baby is kept alive (Nuffield Council 2006; Svendsen 2014; see also Heinsen, this volume).

${ }^{2}$ As Strathern has highlighted there has been concern about the selective potentials of reproductive technologies from the very beginning as she showed how the authors of the Glover Report on Reproductive Technologies to the European Commission from 1989 suggested that in the future 'gene therapy and embryo research... will enable us to influence the kinds of people who are born' (Strathern 1992: 31).
} 